\title{
OPTIMIZING PROCESS PARAMETERS OF CLAY-BASED CERAMICS WITH ADDITION OF CONSTRUCTION AND DEMOLITION WASTE*
}

Biljana Angjusheva ${ }^{1, * \star}$, Vilma Ducman², Monika Fidancevska1, ${ }^{1}$ Vojo Jovanov

${ }^{1}$ Faculty of Technology and Metallurgy, Ss Cyril and Methodius, University in Skopje, Skopje, R. of N. Macedonia,

${ }^{2}$ Slovenian National Building and Civil Engineering Institute, Ljubljana, Slovenia

Construction and demolition waste produced in the Republic of North Macedonia remains a major economic and environmental problem because all construction and demolition waste ends up in local dumps or is disposed of in a landfill. The objective of this study was to investigate the influence of the process parameters on the physical and mechanical properties of clay-based ceramics with partial replacement of clay with construction and demolition waste. Determination of the chemical composition of the waste demolition brick using $\mathrm{X}$-ray fluorescence showed that it consisted of different oxides such as $\mathrm{SiO}_{2}, \mathrm{Al}_{2} \mathrm{O}_{3}, \mathrm{Fe}_{2} \mathrm{O}_{3}$ and $\mathrm{CaO}$ and minor contents of alkaline and earth alkaline oxides. Production of these ceramics was conducted through the consolidation of clay and waste demolition brick with the evaluation of the main process parameters such as sintering temperature $[\mathrm{ST}]$, the content of waste demolition brick [WDB] and isothermal period at the final temperature [IP]. The final model equations for density and bending strength dependence of the main process parameters were obtained and presented. The microstructure of the ceramics determined by SEM shows that the waste material is homogeneously dispersed in the clay matrix.
(ORIGINAL SCIENTIFIC PAPER) UDC 628.477.6:666.3/.7 (497.7) DOI 10.5937/savteh2102061A

Keywords: construction and demolition waste, clay, process parameters, bending strength, density

\section{Introduction}

In recent years, worldwide researchers are putting intense efforts and are focusing on the development of different types of ecologically sustainable composites which could serve as sustainable alternatives to traditional ceramics. One efficient way to reduce natural raw materials in ceramics is to partially (or completely) replace it with secondary materials generated from the construction, demolition and renovation of buildings, as well as civil infrastructure. The construction and demolition waste (CDW) is considered as one the most immense waste stream generated in the EU, and according to the European List of Waste [1] it consists of various materials such as concrete, bricks, wood, metals, plastic, glass, asbestos and excavated soil, gypsum, many of which can be recycled. The European Commission reports that approximately $25-30 \%$ of all waste produced within the $\mathrm{EU}$ is $\mathrm{CDW}$, with recycling levels varying within member states from 10-90\% [2]. In R. North Macedonia CDW is estimated at 600,000 tons per annum or $2 \%$ of total waste [3]. Currently, this waste is not disposed of in accordance with the EU directive with most of it being illegally disposed of in "wild dumps" as there is no formal collection system. There are many scientific reports and proven methods for dealing with CDW, like implementing it in pavements, concrete bricks and blocks, mortars, alkali-activated cement, etc. [4-8]. Authors [9] reported that it was possible to add $20 \%$ of CDW to clay without compromising the strength which is in line with the figures reported by Hoat and Srivastava [10]. Demir and Orhan added 30\% of CDW mass while maintaining the strength [11]. In this study, the focus was recycling and reusing demolition waste bricks in clay-based ceramics and optimizing process parameters for their production. This design was particularly useful for this research because it required fewer treatment combinations of the parameters such as sintering temperature, content of the waste brick and isothermal period at the final temperature. Furthermore, this design helped to stay as close as possible to the observed values as well as to obtain model equations for the physical and mechanical properties of claybased ceramics.

\section{Materials and methods}

The samples of demolition waste used in this study were collected at local construction/demolition sites in Skopje, and the clay was collected from the eastern part of Republic of North Macedonia. The waste demolition brick samples were coded WDB. The raw

\footnotetext{
*The paper was presented at 14th Symposium with international participation "NOVEL TECHNOLOGIES AND ECONOMIC DEVELOPMENT", Faculty of Technology in Leskovac, 22-23 October, 2021.

${ }^{* *}$ Author address: Biljana Angjusheva, Faculty of Technology and Metallurgy, Ss Cyril and Methodius, University in Skopje, Rudger Boshkovic 161000 Skopje R. of N. Macedonia,

E-mail: biljana@tmf.ukim.edu.mk

The manuscript received: April, 03, 2021.

Paper accepted: June, 14, 2021.
} 
materials were manually crushed and then ground up in a planetary mill (Fritsch pulverisette 5) for 30 minutes and screened through a $125 \mu \mathrm{m}$ screen. The particle size distribution of the WDB and clay $(-0.125 \mathrm{~mm})$ was determined by laser granulometry (Laser Cilas 1090). The chemical composition was determined with an XR Fluorescence model ARL 9900XP. The picnometric method was used to define the density of both starting materials. The phase composition of the clay was determined by X-ray diffraction (Philips PW 1710). The investigations were done under the following conditions: monochromatic CuKa radiation with $\lambda=1.5418 \mathrm{~A}$ in the $5-55^{\circ}$ of $2 \theta$ range, scan rate $0.02^{\circ}, 0.5$ s per step. The specific surface area of the demolished brick was estimated by the Blaine method, according to the standard (EN-196-2).

The waste demolished brick (WDB) in the quantity of 10, 20 and 30 wt.\% was incorporated in the clay matrix. The consolidation of the clay samples and WDB was performed by pressing the powders in a uniaxial press (Weber Pressen KIP 100) at $P=68$ MPa using water as a binder. Sintering of the compacted samples (with dimensions $50 \mathrm{~mm} \times 5 \mathrm{~mm} \times 5 \mathrm{~mm}$ ) was done in a chamber furnace using a heating rate of $10^{\circ} \mathrm{C} / \mathrm{min}$. The bulk density of the sintered samples was determined by the water displacement method according to EN-993. The bending strength was measured on the sintered samples which were subjected to a 3-point bending strength tester (Netsch 401/3) with a $30 \mathrm{~mm}$ span and a $0.5 \mathrm{~mm} /$ min loading rate.

The evaluation of the influence of the main process parameters such as brick content, sintering temperature and isothermal time on the physical properties of dense ceramics was based on the design of the experiment. The Response Surface Design and the Statgraphics Centurion software package were used for that purpose. he results as shown in the Pareto chart, the main effects plot and the 3D surface model for the investigated responses are presented in graphical and analytical form.

\section{Results and discussion}

The chemical composition of waste demolished brick (WDB) and clay is presented in Table 1.

Table 1. Chemical composition of WDB and clay

\begin{tabular}{lllllllllll}
\hline Oxides & $\mathrm{SiO}_{2}$ & $\mathrm{Fe}_{2} \mathrm{O}_{3}$ & $\mathrm{Al}_{2} \mathrm{O}_{3}$ & $\mathrm{CaO}$ & $\mathrm{MgO}$ & $\mathrm{Na}_{2} \mathrm{O}$ & $\mathrm{K}_{2} \mathrm{O}$ & $\mathrm{SO}_{3}$ & LOI & Total \\
wDB,wt.\% & 61.12 & 8.45 & 17.58 & 7.82 & 3.59 & 0.33 & 0.29 & 0.18 & 0.86 & 99.64 \\
Clay, wt.\% & 58.79 & 9.28 & 13.60 & 3.01 & 1.72 & 3.83 & 2.51 & $/$ & 5.79 & 99.11
\end{tabular}

The chemical composition shows the presence of typical oxides: $\mathrm{SiO}_{2}$ and $\mathrm{Al}_{2} \mathrm{O}_{3}$ (lower presence of $\mathrm{CaO}$, $\mathrm{MgO}, \mathrm{Na}_{2} \mathrm{O}, \mathrm{K}_{2} \mathrm{O}$ ) accompanied by 8.45 wt. $\% \mathrm{Fe}_{2} \mathrm{O}_{3}$. The higher $\mathrm{CaO}$ content (7.82 wt. \%) in WDB is associated with the presence of cement in the waste material and will affect the sintering behaviour of the clay product.
The specific gravity of the demolished bricks and clay was $2.65 \mathrm{~g} / \mathrm{cm}^{3}$ and $2.70 \mathrm{~g} / \mathrm{cm}^{3}$, respectively, while the specific surface area of the demolished bricks was 0.5597 $\mathrm{m}^{2} / \mathrm{g}$. The mineralogical composition of the clay (Fig. 1) shows that it is illite type of clay with the presence of quartz, feldspar and kaolinite. The granulometric compositions of the demolished bricks and clay are presented in Figure 2. Figure 2 shows that both raw materials have a bimodal particle size distribution. The first interval of the particle size distribution of the demolition waste and clay was from 0.1 to $5 \mu \mathrm{m}$ and the second part was from 5 to $90 \mu \mathrm{m}$ for WDB and $130 \mu \mathrm{m}$ for clay. The D50 for WDB and clay were 12.33 and $17.99 \mu \mathrm{m}$, respectively.

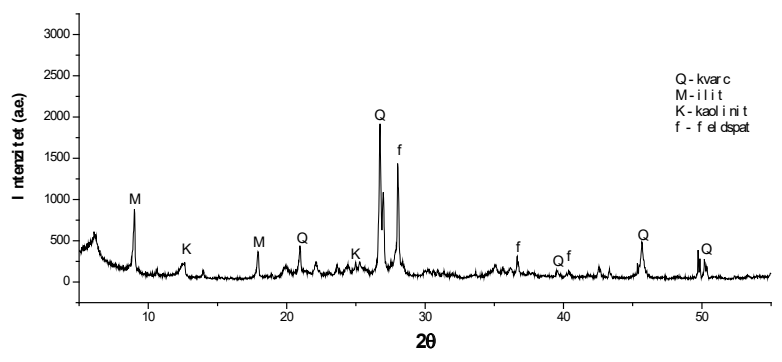

Figure $1 \mathrm{XRD}$ data for investigated clay

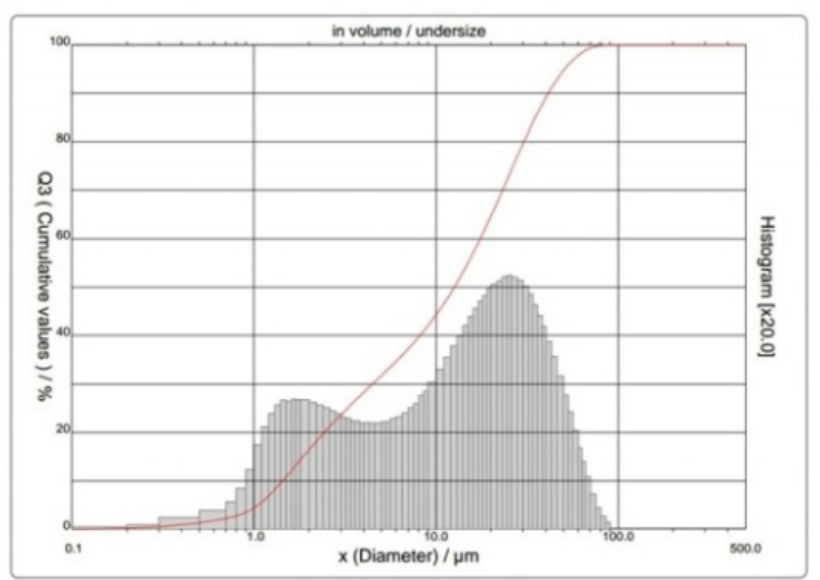

(a)

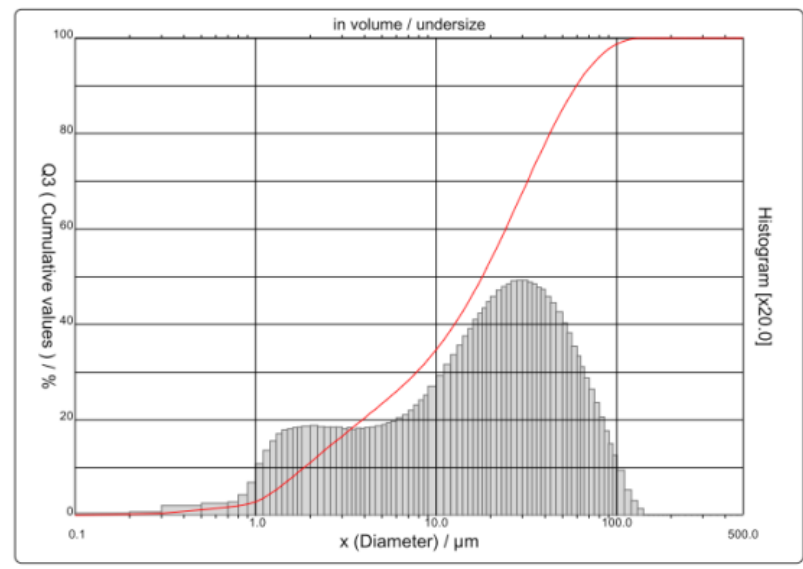

(b)

Figure 2 Granulometric composition of a) WDB and b) clay 


\section{Optimization process}

Density

The first optimization process was conducted by investigating the influence of the sintering temperature, waste demolition brick content and isothermal time as process variables on the density of the ceramics as a response function. The results of this optimization are presented in the following figures (Figs. 3 and 4).

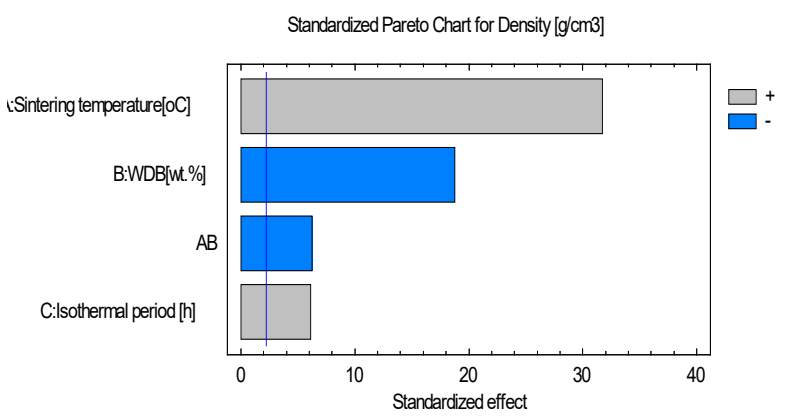

(a)

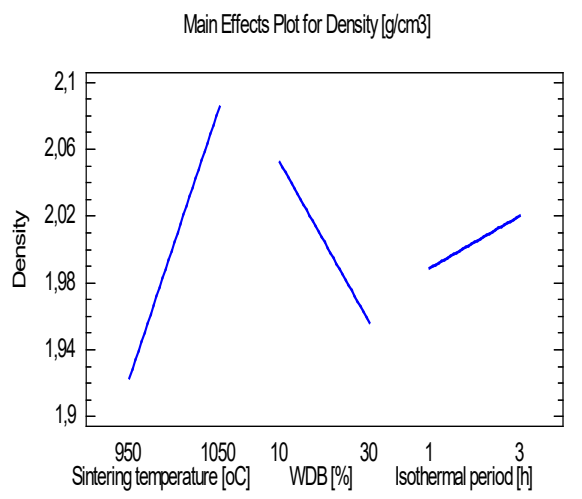

(b)

Figure 3 (a) Pareto chart of main parameters; (b) Main effects and their interactions of the parameters on the density of the clay-based ceramics

In this case of optimization, it can be concluded that the density of the ceramic compacts is directly dependent on the sintering temperature as the main process parameter, while the WDB content and the isothermal period are less influential on the density of clay-based ceramics compared to the sintering temperature (Fig. 3a). Higher sintering temperatures, lower brick content and longer isothermal time are favourable for higher density performance of the WDB compacts (Fig. 3b).

In line with the obtained data from the software package, according to the influences of the main parameters, the final model equation for density $\left(\mathrm{g} / \mathrm{cm}^{3}\right)$ is presented as:

Density $=-0.455667+0.002525^{*} \mathrm{ST}+0.0401875^{*} \mathrm{WDB}+$ $0.015625^{*} \mathrm{IP}-0.000045^{*} \mathrm{ST} * \mathrm{WDB}[\mathrm{g} / \mathrm{cm} 3]$ where ST is the sintering temperature $\left({ }^{\circ} \mathrm{C}\right)$, WDB is the waste demolition brick content (wt.\%), and IP is the isothermal period (hours). The graphical form of the equation is shown in Fig. 4. Also, the optimal maximum of the density is located at the bottom right corner of the 3D diagram.

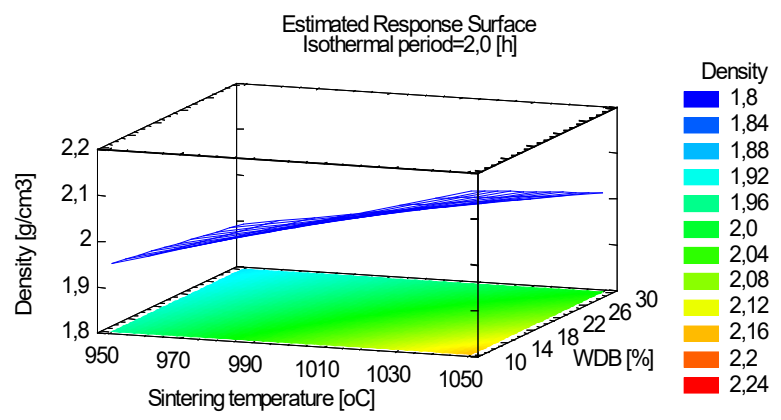

Figure 4 3D optimization diagram of the main effects at constant isothermal period, and variable sintering temperature and WDB content

\section{Bending strength}

In the case of optimization of the response value, the bending strength of the dense compacts was also examined as a function of the process parameters - brick content, sintering temperature, isothermal period.Optimization diagrams are presented in Figures 5 and 6 . It is noticeable that the bending strength of the dense compacts is directly dependent on the WDB content and sintering temperature as the main process parameters, while the isothermal period is less influential on the bending strength of the specimens (Fig. $5 a$ and $5 b$ ).

Lower brick content, higher sintering temperatures, and a longer isothermal period are favourable for better performance of clay-based compacts (Fig. 5a and 5b). From the data obtained from the software package, the final model equation for bending strength (MPa) is presented as:

Bending strength $=-53,2333+0,08^{*} \mathrm{ST}-0,35^{*} \mathrm{WDB}+$ $2,25^{*} \mathrm{IP}-0,05^{*} \mathrm{WDB}^{*} \mathrm{IP}[\mathrm{MPa}]$

where ST is the sintering temperature $\left({ }^{\circ} \mathrm{C}\right)$, WDB is the waste demolition brick content (wt.\%), and IP is the isothermal period (hours). Also, the 3D optimization diagram displays the optimal maximum for the bending strength in the bottom right corner in Fig.6. 


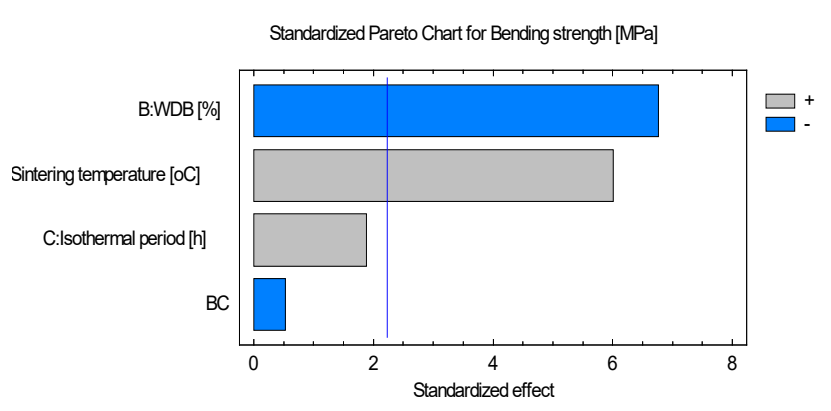

(a)

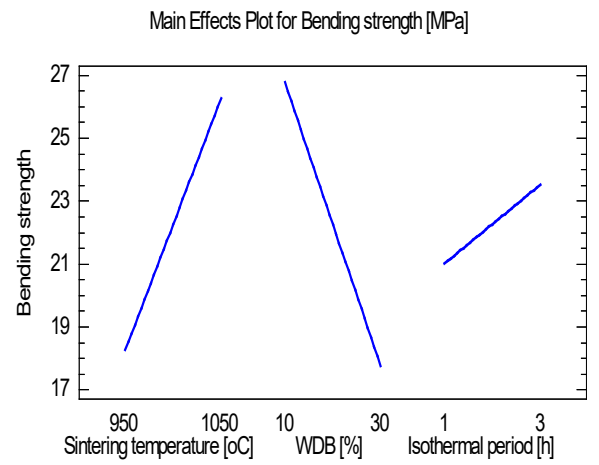

(b)

Figure 5 (a) Pareto chart of main parameters; (b) Main effects and their interactions of the parameters on the bending strength of clay-based ceramics

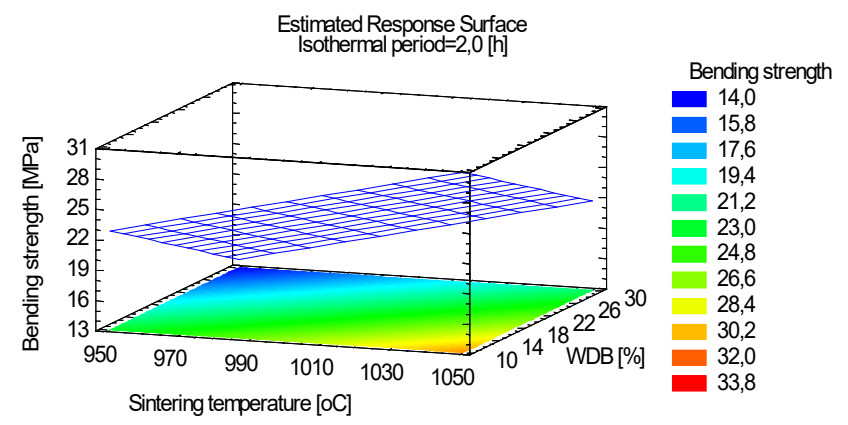

Figure $63 \mathrm{D}$ optimization diagram of the main effects at constant isothermal period, and variable sintering temperature and WDB content

\section{Microstructure of the ceramics}

The microstructure of the obtained ceramics from clay and $30 \mathrm{wt} \% \mathrm{WDB}$ sintered at $950^{\circ} \mathrm{C}$, and $1050{ }^{\circ} \mathrm{C}$ are presented in Figures 7 and 8 . The microstructure of the fractured sample sintered at $1050{ }^{\circ} \mathrm{C}$, (Fig. 8) shows a slightly more uniform surface compared to the sample sintered at $950^{\circ} \mathrm{C}$ (Fig. 7) Close irregular pores are more common in the specimen shown in Fig. 7, probably due to the lower sintering temperature. Small cracks are also visible in both microstructures which could be due to the shrinkage of the samples during the cooling.

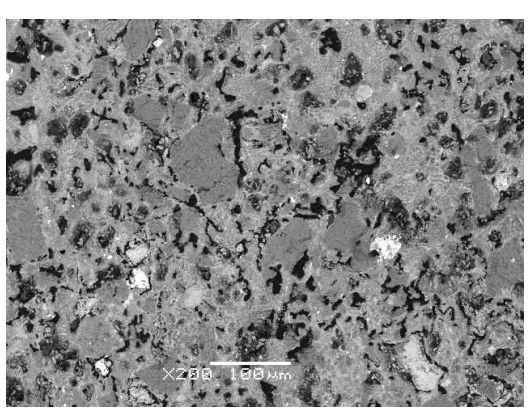

(a) $\times 200$, bar $100 \mu \mathrm{m}$

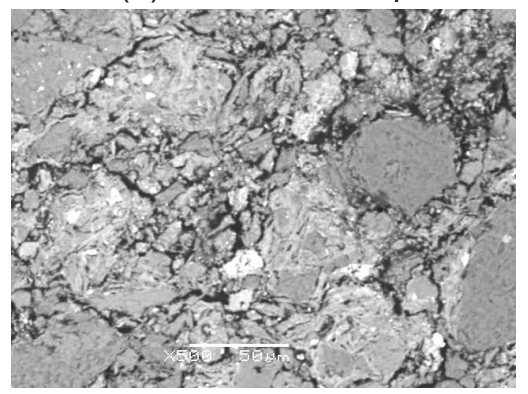

(b) $\times 500$, bar $500 \mu \mathrm{m}$

Figure 7 Microstructure of the ceramics and 30 wt. \%WDB, sintered at $950^{\circ} \mathrm{C} / 1 \mathrm{~h}$

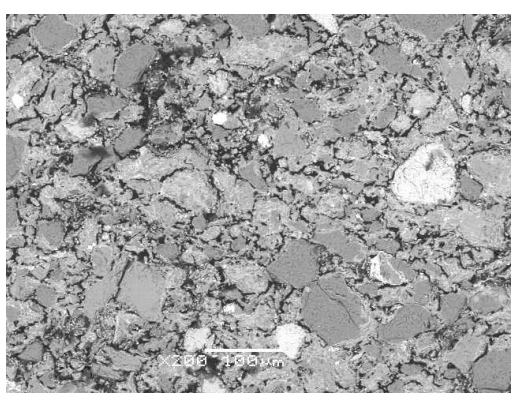

(a) $\times 200$, bar $100 \mu \mathrm{m}$

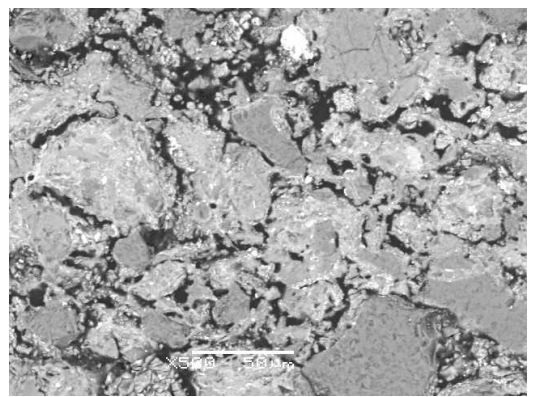

(b) $\times 500$, bar $500 \mu \mathrm{m}$

Figure 8 Microstructure of the ceramics and 30 wt.\% WDB, sintered at $1050{ }^{\circ} \mathrm{C} / 1 \mathrm{~h}$

\section{Conclusion}

In these investigations, demolition waste from local construction/demolition sites in Skopje, R. of North Macedonia was used as partial replacement of clay in clay-based ceramics. To determine the optimal operating areas, the Response Surface Design class was successfully applied. The final model equations for the den- 
sity and bending strength as response functions were obtained.

The microstructure of the obtained ceramics sintered at $950{ }^{\circ} \mathrm{C}$, and $1050{ }^{\circ} \mathrm{C}$ shows that 30 wt. \% WDB is homogeneously dispersed in the clay matrix.

The use of Statgraphics Centurion software package and Response Surface Design, may be an innovative way to optimize process parameters included in claybased ceramics production and possible partial replacement with construction and demolition waste.

\section{Acknowledgement}

The authors thank the COSTAction MINEA(CA15115) for the financial support for this investigation realized through STS mission.

\section{References}

[1] EU Commission Decision of 18 December $2014 \mathrm{n}$. 2014/955/EU. Official Journal of the European Union n. L $370 / 44$ of 30.12 .2014 .

[2] Eurostat, European Commission, "Enviroment-Waste," 9 August 2018. Available:http://ec.europa.eu/environment/ waste/construction_demolition.htm. (Accessed 7 June 2020).

[3] Ministry of environment and physical planning.http:// www.moepp.gov.mk/ wp-content/uploads/2014/12/ Waste-Management-Strategy-of-the-RM-2008-2020.pdf, (Accessed 17 June 2020).

[4] J. Silva, J. De Brito, R. J. Veiga, Recycled Red-Clay Ceramic Construction and Demolition Waste for Mortars Production, Journal of Materials in Civil Engineering, 22 (3) (2010) 236-244.
[5] F. C. Leite, R. S. Motta, K. L. Vasconcelos, L. Bernucci, Laboratory evaluation of recycled construction and demolition waste for pavements, Construction and building materials, 25 (6) (2011) 2972-2979.

[6] R. A. Robayo-Salazar, J. F. Rivera, R. M. Gutiérrez, Alkali-activated building materials made with recycled construction and demolition wastes, Construction and building materials, 149 (2017) 130-138.

[7] C. S. Poon, S. C. Kou, L. Lam, Use of recycled aggregates in molded concrete bricks and blocks, Construction and Building Materials, 16 (5) (2002) 281-289.

[8] S. K. Amin, H. A. Sibak, S. A. El-Sherbiny, M. F. Abadir, An Overview of Ceramic Wastes Management in Construction, International Journal of Applied Engineering Research, 11 (4) (2016) 2680-2685.

[9] M. Baroso and $\mathrm{H}$. Pala, http://www. scienceknowconferences.com/files/ extended_abstracts/ ewwm2016/Incorporation $\% 20$ of $\% 20$ construction $\% 20$ and $\% 20$ demolition $\% 20$ waste $\% 20$ in $\% 20$ the $\% 20$ production $\% 20$ of $\% 20$ ceramic\%20brick.pdf,

(2017), (Accessed 20 September 2020).

[10] S. Hoat, V. Srivastava, Partial Replacement of Fine Aggregate with Ceramic and Demolition waste in Rigid Pavement, International Journal of Innovative Science Engineering and Technology, 5 (8) (2016) 2347-6710.

[11] I. Demir, M. Orhan, Building and Environment, Reuse of waste bricks in the production line, 38 (12) (2003) 14511455.

\section{Izvod}

\section{OPTIMIZACIJA PROCESNIH PARAMETARA KERAMIKE NA BAZI GLINE SA DODATKOM GRAĐEVINSKOG OTPADA I OTPADA OD RUŠENJA}

Biljana Angjusheva' ${ }^{1}$, Vilma Ducman², Monika Fidancevska ${ }^{1}$, Vojo Jovanov ${ }^{1}$

\footnotetext{
${ }^{1}$ Tehnološki i metalurški fakultet, Sv Ćirilo i Metodije, Univerzitet u Skoplju, Skoplje, Republika Makedonija

2Slovenački nacionalni institut za građevinarstvo, Ljubljana, Slovenija
}

Građevinski otpad i otpad nastao od rušenja koji nastaje u Republici Severnoj Makedoniji ostaje veliki ekonomski i ekološki problem jer sav građevinski otpad i otpad od rušenja završava na lokalnim deponijama. Cilj ovog rada bio je da se ispita uticaj procesnih parametara na fizička i mehanička svojstva keramike na bazi gline sa delimičnom zamenom gline građevinskim otpadom i otpadom od rušenja. Određivanje hemijskog sastava otpadne cigle za rušenje pomoću rendgenske fluorescencije pokazalo je da se ona sastoji od različitih oksida kao što su $\mathrm{SiO}_{2}, \mathrm{Al}_{2} \mathrm{O}_{3}$, $\mathrm{Fe}_{2} \mathrm{O}_{3}$ i $\mathrm{CaO}$ i manjeg sadržaja alkalnih i zemnoalkalnih oksida. Proizvodnja ove keramike odvijala se kroz konsolidaciju gline i otpadne opeke za rušenje uz procenu glavnih parametara procesa kao što su temperatura sinterovanja [ST], sadržaj otpadne opeke za rušenje [VDB] i izotermni period na krajnjoj temperaturi [IP]. Dobijene su i prikazane konačne jednačine modela za zavisnost od gustine i čvrstoće na savijanje glavnih parametara procesa. Mikrostruktura keramike određena primenom SEM pokazuje da je otpadni materijal homogeno dispergovan u glinenoj matrici.
(ORIGINALNI NAUČNI RAD) UDK 628.477.6:666.3/.7 (497.7) DOI 10.5937/savteh2102061A

Ključne reči: građevinski i otpad od rušenja, glina, procesni parametri, čvrstoća na savijanje, gustina 